\title{
Topical application of a melanotropin analogue to vulgar vitiligo dermo-epidermal minigrafts
}

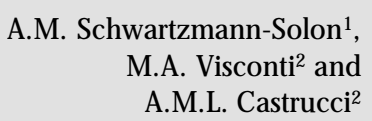

\author{
${ }^{1}$ Hospital Municipal Dr. Fernando Mauro Pires da Rocha and \\ ${ }^{2}$ Departamento de Fisiologia, Instituto de Biociências, \\ Universidade de São Paulo, SP, Brasil
}

\section{Correspondence \\ A.M.L. Castrucci \\ Departamento de Fisiologia \\ IB, USP \\ Caixa Postal 11176 \\ 05422-970 São Paulo, SP \\ Brasil \\ Fax: + 55-11-818-7422 \\ E-mail: amdlcast@usp.br \\ Research supported by FINEP, CNPq, and FAPESP.}

Received September 23, 1997 Accepted September 24, 1998

\begin{abstract}
Human subjects with active vulgar vitiligo do not respond well to autologous dermo-epidermal minigrafting. Eighteen subjects were treated with the $\alpha$-melanocyte-stimulating hormone ( $\alpha$-MSH) synthetic analogue $\left[\mathrm{Nle}^{4}, D-\mathrm{Phe}^{7}\right]-\alpha-\mathrm{MSH}$. The hormone $(50 \mu \mathrm{l}, 0.4 \mathrm{mM})$ was applied topically to $30-\mathrm{cm}^{2}$ lesions in which $29-48$ minigrafts had been made. The hormone did not improve the success of the minigrafting and no differences were observed in local or distant repigmentation in treated subjects as compared to the placebo group. Aliquots of 24-h urine concentrated by lyophilization irreversibly darkened toad skins, demonstrating the presence of the analogue. This is the first report of the transdermal delivery of a topically applied melanotropin in living human subjects.
\end{abstract}

\author{
Key words \\ - Vulgar vitiligo \\ - $\alpha$-M SH synthetic analogue \\ - M inigrafting
}

\section{Introduction}

Vitiligo is a pigmentation disorder that affects 0.5 to $4 \%$ of the world population. Its etiology is unknown, and the symptoms probably result from a variety of pathogenic alterations of the immune and neural systems, and of melanocyte structure and function (18).

The pigmentation of most vertebrates is regulated by $\alpha$-melanocyte-stimulating hormone $(\alpha-\mathrm{MSH})$ secreted by the pars intermedia of the pituitary. The hormone is produced by the cleavage of proopiomelanocortin, which is also the precursor protein of ACTH, $\beta$-endorphins and $\gamma$-MSH. In humans, the pars intermedia is non-functional, but $\alpha-$ MSH is produced locally in the skin by Langerhans cells, keratinocytes and melanocytes themselves $(9,10)$. Five melanocortin receptors belonging to the family of G-proteincoupled receptors have been cloned $(11,12)$. The MC1 receptor is specific for the integumental melanocytes and active macrophages, and is highly selective for $\alpha-\mathrm{MSH}$ (13). It has recently been demonstrated that $\alpha-\mathrm{MSH}$ stimulates melanin synthesis and proliferation in human cultured melanocytes $(14,15)$.

Various $\alpha$-MSH analogues have been synthesized during the last decade by Hadley and colleagues (16-18). The [Nle $\left.{ }^{4}, D-\mathrm{Phe}^{7}\right]$ $\alpha$-MSH analogue, a superpotent agonist of mammalian melanocytes, is $100-1000$ times more potent than the native hormone. Unlike the native hormone, it is resistant to inactivation by serum and brain enzymes, and by purified proteolytic enzymes $(16,17)$. The synthetic hormone exhibited no toxicologic 
effects nor did it favor tumor growth, metastasis or invasion in mice $(19,20)$ and therefore was tested in humans. When intravenously injected $(0.16 \mathrm{mg} / \mathrm{kg})$ daily for 10 days, the peptide enhanced the epidermal pigmentation of healthy male subjects, with no significant side effects (21).

The analogue is highly lipophilic, being able to pass through the skin of mice and human cadavers (18), and might therefore be transdermally delivered. Topical application might be more efficient than injection, with higher availability at the hair follicle level, while liver metabolism and excretion into urine should be reduced or avoided.

We and others have previously reported that dermo-epidermal minigrafts were very effective in repopulating hypopigmentary lesions in segmental vitiligo patients, but much less effective for the vulgar type $(22,23)$.

Since transplants provide viable melanocytes, our objective was to investigate in vulgar vitiligo patients: 1) the efficacy of topical application of $\left[\mathrm{Nle}^{4}, D-\mathrm{Phe}^{7}\right]-\alpha-\mathrm{MSH}$ in stimulating melanocyte proliferation and melanocyte or melanosome spread from the dermo-epidermal grafts, and 2) the efficiency of transdermal delivery of the MSH analogue topically applied in vivo on those lesions.

\section{Material and Methods}

\section{Subjects}

Eighteen volunteers (15 men and 3 women) with vulgar vitiligo were selected. The duration of the disease varied from 3 to 46 years, with an average of 20.5 years (Table 1). Among the patients, 12 exhibited active dysfunction, that is, newly arisen achromic lesions, and 3 presented the Koebner phenomenon (Table 1). Some patients exhibited variable degrees of leukotrichia. Since most areas chosen for the study were hairless or bore a small vellus, this characteristic was not used as a parameter. The patients were submitted to the following blood tests: complete blood counts, glutamic-oxaloacetic acid transaminase (GOT), glutamic-pyruvic acid transaminase (GPT), alkaline phosphatase, glycemia, T3, T4, TSH, and early morning (8 a.m.) cortisol, immediately before and 4 months after the beginning of the treatment.

\section{Minigrafting}

A $30-\mathrm{cm}^{2}$ skin area bearing no internal pigmented spots was chosen in each individual. In 13 subjects the areas were located on the upper limbs as follows: forearm (7 subjects), wrist (4 subjects), arm (1 subject), and hand (1 subject). In two subjects the areas were on the lower limbs, i.e., the leg (1 subject) and the foot (1 subject). Finally, in one subject the area was located on the flank, and in two subjects the areas were on the abdomen.

The number of explants ranged from 29 to 48 depending on the shape of the area. The explants (1 $\mathrm{mm}$ in diameter) were removed from the retroauricular region and grafted 1 $\mathrm{cm}$ apart under local anesthesia with 3\% prilocaine and a vasoconstrictor. Hemostasis was achieved with $50 \%$ iron perchloride, and the graft was occluded with micropore tape.

\section{Treatment with the melanotropin analogue}

Two weeks later, 9 subjects started receiving topical applications of a $0.4 \mathrm{mM}$ solution of $\left[\mathrm{Nle}^{4}, D-\mathrm{Phe}^{7}\right]-\alpha-\mathrm{MSH}$ in polyethyleneglycol 400 (group I), and the other 9 , the placebo control, only polyethyleneglycol 400 (group II). The compositions of both solutions were unknown to the subjects and to the therapist until the end of the experiment.

For 2 months, the volunteers received 50 $\mu l$ of solution I or II, topically applied twice a week by the therapist to the selected depigmented area of $30 \mathrm{~cm}^{2}$. During an addi- 
tional 5-month period, the patients were instructed to self-apply the solution once a day, twice a week, with weekly visits to the therapist. The final dose per application was $36.5 \mu \mathrm{g} / 30 \mathrm{~cm}^{2}\left(2 \times 10^{-8} \mathrm{~mol}\right)$. The evolution of treatment was monitored with the aid of a Woods light.

\section{U rinary melanotropin assay}

In the last week of treatment, 24-h urine was collected from 4 patients, lyophilized and resuspended in $100 \mathrm{ml}$ of distilled water. The precipitate was removed by centrifugation, the supernatant was lyophilized once more and resuspended in $5 \mathrm{ml}$ of distilled water. The solution was assayed in the toad skin bioassay to detect the presence of the $\alpha$ $\mathrm{MSH}$ analogue. The assay is very sensitive and able to detect picomolar concentrations of $\left[\mathrm{Nle}^{4}, D\right.$-Phe $\left.{ }^{7}\right]-\alpha-\mathrm{MSH}$ (24). Three different controls were used: 1) $0.1 \mathrm{nM}\left[\mathrm{Nle}^{4}, D\right.$ $\left.\mathrm{Phe}^{7}\right]-\alpha-\mathrm{MSH}$ was assayed as the positive control; 2) urine from an untreated healthy 34-year-old male volunteer was similarly lyophilized and resuspended as above and assayed as the negative control; 3) an 18-h urine sample from a healthy 46-year-old female volunteer was collected after one topical application of the analogue to $30 \mathrm{~cm}^{2}$ of the forearm, lyophilized, resuspended in 100 $\mathrm{ml}$, and assayed.

The thigh and dorsal body skins of male toads, Bufo ictericus, were removed and placed in Ringer solution containing: 11.2 $\mathrm{mM} \mathrm{NaCl}, 1.9 \mathrm{mM} \mathrm{KCl}, 1.1 \mathrm{mM} \mathrm{CaCl}_{2}, 6.5$ $\mathrm{mM} \mathrm{Na} \mathrm{HPO}_{4}, 1.5 \mathrm{mM} \mathrm{KH} \mathrm{PO}_{4}, \mathrm{pH} 7.30$ 7.45 . Square skin pieces $(2.5 \times 2.5 \mathrm{~cm})$ were mounted individually between two PVC rings and maintained in $10 \mathrm{ml}$ of Ringer at $23^{\circ} \mathrm{C}$ $( \pm 1.0)$ for at least 60 min to provide maximal lightening conditions (maximally aggregated melanosomes). A Photovolt reflectometer was used to measure the reflectance of each skin and an initial mean value was obtained for each group of skins. The addition of increasing doses of a darkening agonist such as the $\alpha$-MSH analogue $\left[\mathrm{Nle}^{4}, D\right.$-Phe $\left.{ }^{7}\right]-\alpha$ $\mathrm{MSH}$ to each group for $60 \mathrm{~min}$ results in a dose-dependent darkening (melanosome dispersion) of the skins (24). The responses to $100 \mu \mathrm{l}$ of the 4 urine samples from topically treated patients were compared to the maximal response evoked by $0.1 \mathrm{nM}\left[\mathrm{Nle}^{4}, D\right.$ $\left.\mathrm{Phe}^{7}\right]-\alpha-\mathrm{MSH}$ and to $100 \mu \mathrm{l}$ of control urine samples. The 60-min readings of reflectance (skin color) were recorded and are reported as percent change of the initial basal value.

The use of human subjects in this investigation was approved by the Ethics Committee of the University Hospital, University of São Paulo, and the patients gave their written informed consent.

\section{Results}

All patients showed good graft implantation, with no necrosis. Two patients abandoned treatment. Therefore, we ended the experimental treatment with 8 patients in each group. Among the 16 volunteers, 5 subjects had abnormal blood tests during evaluation. Subject 4 had hyperglycemia and high levels of serum GOT and GPT, and was hepatitis B anti-e and anti-c positive and HBSAg negative, hepatitis A IgG positive, IgM negative and anti-HCV negative, and had hepatic steatosis before treatment. Subject 5 had a history of a possible gestational diabetes. Subject 10 showed hyperthyroidism and hyperglycemia; subject 16 had diabetes for one year and a half, and subject 11 had hyperthyroidism just before the onset of vitiligo (Table 1). No alteration of laboratory tests during the application of $\left[\mathrm{Nle}^{4}, D-\mathrm{Phe}^{7}\right]$ $\alpha$-MSH, or side effects such as those described after the administration of the analogue to healthy volunteers (21) were observed.

After 2 months, three subjects from group I exhibited a 1-3-mm pigmentation halo around the grafts, and one of them also presented pigmentation spots in distant lesions. The halo presented no further expansion 
during treatment. Four individuals showed pigmentation only in the grafts and one had totally depigmented grafts (Table 2).

In the placebo group, 6 patients kept the pigmentation only in the grafts. In six individuals, pigmentation was observed in distant lesions. Only one patient exhibited a halo surrounding the grafts, but other spots of repigmentation distant from the grafts were also observed. The last subject showed depigmented grafts, but repigmented spots in distant sites (Table 2).

After the first phase, all volunteers started to apply the hormone daily. Twelve people completed the entire 5-month treatment, and 4 abandoned treatment after 3 months.

In the initial group I, two patients abandoned treatment after 3 months, one having depigmented grafts and no other sites of repigmentation, the other exhibiting a highly active expansion of the pigmentation halo, as already observed in phase I. The other 6 volunteers completed the 5 -month period. Among them, two kept the same pigmentation rate at distant sites as before, one exhibited depigmentation of the grafts and pigmentation of distant lesions, one had only pigmented grafts, one exhibited a new achromic spot, and one presented a growing pigmentation halo around the grafts (Table 2).

In group II, two patients also abandoned treatment after 3 months, one exhibiting increasing repigmentation as in phase I, the other with unpigmented grafts and discrete pigmentation of distant spots. The other 6 volunteers completed the experiment. Among them, two had an increasing halo and pigmentation of distant lesions, three developed pigmentation at distant sites, which depigmented during the 4th month, and one exhibited a complete depigmentation of the grafts, but simultaneous appearance of pigmented and hypochromic maculae at various tegumental sites (Table 2).

In summary, during phase $\mathrm{I}$, the control group exhibited a more intense repigmentation of distant lesions. None of the patients bearing halo around the grafts ( 3 of group I and 1 of group II) exhibited any increase in the rate of halo expansion.

Continuous application of the hormonecontaining solution for the subsequent 5 months in all patients (phase II) did not

Table 1 - Clinical data of the subjects.

$\mathrm{M}=\mathrm{M}$ ale; $\mathrm{F}=$ female; spread = body, upper and lower limbs.

\begin{tabular}{|c|c|c|c|c|c|c|c|c|c|c|c|}
\hline Subject & $\begin{array}{c}\text { Sex/age } \\
\text { (years) }\end{array}$ & $\begin{array}{l}\text { Time of disease } \\
\text { (years) }\end{array}$ & $\begin{array}{l}\text { Related } \\
\text { diseases }\end{array}$ & $\begin{array}{l}\text { Affected } \\
\text { areas }\end{array}$ & $\begin{array}{c}\text { Koebner/ } \\
\text { activity }\end{array}$ & Subject & $\begin{array}{c}\text { Sex/age } \\
\text { (years) }\end{array}$ & $\begin{array}{l}\text { Time of disease } \\
\text { (years) }\end{array}$ & $\begin{array}{l}\text { Related } \\
\text { diseases }\end{array}$ & $\begin{array}{l}\text { Affected } \\
\text { areas }\end{array}$ & $\begin{array}{c}\text { Koebner/ } \\
\text { activity }\end{array}$ \\
\hline 1 & $M / 56$ & 24 & & spread & $-1+$ & 9 & $\mathrm{M} / 51$ & 46 & & limbs & $-1+$ \\
\hline 2 & $M / 55$ & 21 & & spread & $-1+$ & 10 & M/55 & 40 & $\begin{array}{c}\text { hyper- } \\
\text { thyroidism } \\
\text { + diabetes }\end{array}$ & spread & $+/+$ \\
\hline 3 & $F / 42$ & 36 & & spread & $-1+$ & 11 & $M / 32$ & 5 & $\begin{array}{l}\text { hyper- } \\
\text { thvroidism }\end{array}$ & spread & $+/+$ \\
\hline 4 & $M / 62$ & 20 & $\begin{array}{l}\text { diabetes } \\
+ \text { hepatic } \\
\text { steatosis }\end{array}$ & spread & $-1+$ & 12 & $M / 49$ & 15 & & spread & $-1+$ \\
\hline 5 & $\mathrm{~F} / 40$ & 14 & $\begin{array}{l}\text { gestational } \\
\text { diabetes }\end{array}$ & spread & $-1+$ & 13 & $M / 46$ & 4 & & spread & $-1+$ \\
\hline 6 & $M / 20$ & 19 & & spread & $-1-$ & 14 & $M / 63$ & 25 & & spread & $-1+$ \\
\hline 7 & $M / 51$ & 3 & & spread & $-1-$ & 15 & $M / 29$ & 14 & & spread & $-1-$ \\
\hline 8 & $M / 29$ & 24 & & spread & $-1-$ & 16 & $F / 35$ & 20 & diabetes & spread & $+/+$ \\
\hline
\end{tabular}


result in any improvement of repigmentation in either group (Table 2).

Despite the lack of effect, the analogue was transdermally delivered, as indicated by the fact that the urine samples from 2 of the 4 sorted subjects and from the healthy volunteer exhibited an irreversible darkening activity on the toad skin assay (Figure 1). Compared to the maximal darkening response elicited by $0.1 \mathrm{nM}\left[\mathrm{Nle}^{4}, D-\mathrm{Phe}^{7}\right]-\alpha-\mathrm{MSH}$, the patient urines were able to promote $50 \%$ of the maximal response. Therefore, its concentration on the toad skins might be calculated as $0.03 \mathrm{nM}$, and in the final urine solution as $3 \mathrm{nM}$.

\section{Discussion}

Various treatments have been employed in an attempt to cure vitiligo, such as psoralens associated with ultraviolet light A (PUVA), corticoids, prostaglandin inhibitors, phenylalanine, di-hydroxyphenylalanine, 5-fluorouracil, melagenin and minigrafts $(23,25)$.

Since $\left[\mathrm{Nle}^{4}, D\right.$-Phe $\left.{ }^{7}\right]-\alpha-\mathrm{MSH}$ was effective in tanning healthy human subjects after daily injections with no toxic effects (21),

Table 2 - Summary of the responses of 16 subjects to topical application of [Nle ${ }^{4}$, D-Phe $\left.{ }^{7}\right]-\alpha-M S H$.

1st Phase: 2 months after the minigrafts

\begin{tabular}{|c|c|c|c|c|c|c|c|c|c|}
\hline \multicolumn{5}{|c|}{ Homone analogue } & \multicolumn{5}{|c|}{ Placebo } \\
\hline Subject & $\begin{array}{l}\text { Pigmentation } \\
\text { halo (>1 mm) }\end{array}$ & $\begin{array}{c}\text { Graft } \\
\text { pigmentation } \\
\text { only }\end{array}$ & $\begin{array}{l}\text { Repigmentation } \\
\text { at a distance }\end{array}$ & $\begin{array}{c}\text { Graft } \\
\text { depigmentation }\end{array}$ & Subject & $\begin{array}{l}\text { Pigmentation } \\
\text { halo (>1 mm) }\end{array}$ & $\begin{array}{c}\text { Graft } \\
\text { pigmentation } \\
\text { only }\end{array}$ & $\begin{array}{l}\text { Repigmentation } \\
\text { at a distance }\end{array}$ & $\begin{array}{c}\text { Graft } \\
\text { depigmentation }\end{array}$ \\
\hline 1 & & & & + & 9 & + & & + & \\
\hline 2 & & + & & & 10 & & + & + & \\
\hline 3 & & + & & & 11 & & + & & \\
\hline 4 & + & & & & 12 & & + & + & \\
\hline 5 & & + & & & 13 & & & + & + \\
\hline 6 & + & & & & 14 & & + & + & \\
\hline 7 & + & & + & & 15 & & + & + & \\
\hline 8 & & + & + & & 16 & & + & & \\
\hline
\end{tabular}

2nd Phase: 5 months after hormone application to both groups

\begin{tabular}{|c|c|c|c|c|c|c|c|c|c|c|c|}
\hline Subject & $\begin{array}{c}\text { Pigmentation } \\
\text { halo } \\
(>1 \mathrm{~mm})\end{array}$ & $\begin{array}{c}\text { Graft } \\
\text { pigmenta- } \\
\text { tion only }\end{array}$ & $\begin{array}{c}\text { Repigmenta- } \\
\text { tion at a } \\
\text { distance }\end{array}$ & $\begin{array}{c}\text { Graft } \\
\text { depig- } \\
\text { mentation }\end{array}$ & $\begin{array}{c}\text { Depig- } \\
\text { mentation } \\
\text { at a } \\
\text { distance }\end{array}$ & Subject & $\begin{array}{c}\text { Pigmentation } \\
\text { halo } \\
(>1 \mathrm{~mm})\end{array}$ & $\begin{array}{c}\text { Graft } \\
\text { pigmenta- } \\
\text { tion only }\end{array}$ & $\begin{array}{c}\text { Repigmenta- } \\
\text { tion at a } \\
\text { distance }\end{array}$ & $\begin{array}{c}\text { Graft } \\
\text { depig- } \\
\text { mentation }\end{array}$ & $\begin{array}{c}\text { Depig- } \\
\text { mentation } \\
\text { at a } \\
\text { distance }\end{array}$ \\
\hline 1 & & & & + & & 9 & + & & + & & \\
\hline 2 & & + & & & & 10 & & + & + & & \\
\hline 3 & & + & + & & + & 11 & & + & + & & \\
\hline 4 & + & & & & + & 12 & & & & + & \\
\hline 5 & & & & + & + & 13 & & & & + & + \\
\hline 6 & + & & & & & 14 & & & & + & + \\
\hline 7 & + & & + & & & 15 & + & & + & & \\
\hline 8 & & + & + & & & 16 & & & & + & + \\
\hline
\end{tabular}


Figure 1 - Percent darkening of Bufo ictericus toad skins in response to $0.1 \mathrm{nM}\left[\mathrm{Nle}^{4}, \mathrm{D}\right.$ $\left.\mathrm{Phe}^{7}\right]-\alpha-\mathrm{MSH}$ (ND- $\alpha-\mathrm{MSH}$; considered as $100 \%$ ) and to lyophilized urine samples from treated and untreated (control) human subjects. Each bar is the mean \pm SEM $(\mathrm{N}=6)$ value for skin darkening. $* \mathrm{P}<0.05 \mathrm{com}$ pared to control (ANOVA followed by Student-NewmanKeuls test).

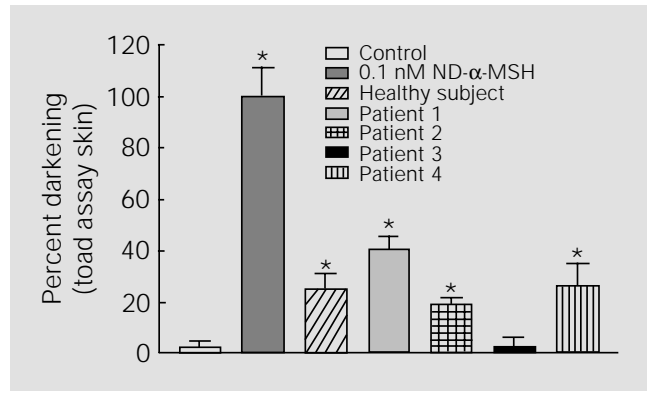

we decided to investigate its effectiveness as a topical agent, on lesions with newly grafted melanocytes in vulgar vitiligo, and to determine if the analogue crossed the transdermal barrier in vivo.

However, our data demonstrated that the analogue did not improve the already expected poor repigmentation with minigrafts in unstable vulgar vitiligo lesions. To have a local effect, the peptide would have to reach the epidermal melanocytes, and the capillaries of the papillar dermis would account for the systemic distribution. Therefore, the reticular dermis would not constitute a barrier (18). It has been reported that facial and head skins were the most permeable regions for the absorption of peptides in vitro. The limbs appear to have a mild degree of permeability, whereas trunk skin appears to be the least permeable due to its thickness and fewer skin adnexa (18). The urine samples from the randomly selected subjects had a darkening effect on toad skin, demonstrating that the peptide had crossed the transdermal barrier and reached the systemic circulation, being therefore available to act on the entire tegument. This is the first report of transdermal delivery of a topically applied peptide hormone analogue in living human subjects.

Boissy and colleagues (6) reported that cultured melanocytes from vitiligo patients exhibited structural defects of the endoplasmic reticulum, such as dilations or circular shapes, in addition to alterations in melanosome compartmentalization. These morphological alterations could also be seen in pig- mented and apparently healthy skin $90 \mathrm{~cm}$ from the achromic lesion. This might be one reason for the ineffectiveness of the hormone treatment. In addition, several authors (26-28) have pointed out that the stability of the segmental or vulgar vitiligo is a requirement for the success of treatments such as skin grafting. In fact, $66.7 \%$ of our patients had unstable vitiligo, which might also be the reason for the negative response to the peptide.

As previously reported $(22,26,29)$, segmental vitiligo may be considered a more stable form than vulgar vitiligo, thus allowing a more successful melanocyte transplantation. Whether healthy skin melanocytes exhibit any metabolic or structural modifications in this type of hypopigmentation remains to be investigated. However, it seems that, regardless of vitiligo activity, once the lesion is superficially dermabrased, autologous cultured melanocytes or epidermal sheets grown in vitro are successfully implanted (30).

One should also bear in mind that the normal phenotypic expression of melanocytes, i.e., melanin synthesis, depends on the interaction of a variety of local peptide hormones, such as endothelins (ETs), basic fibroblast growth factor (bFGF), and agouti protein (31). Both ET-1 and bFGF potentiate the proliferative effect of $\alpha-\mathrm{MSH}$, but are antagonists of melanotropins concerning melanogenesis since they depress the activity and expression of tyrosinase, the key enzyme for melanin synthesis. The agouti protein has been considered to be the physiological regulator of pheomelanin (32), and the inverse agonist of the MCR $1 \alpha-\mathrm{MSH}$ receptor (32). The 108-amino acid peptide is produced in the mammalian hair follicle and binds to the $\alpha-\mathrm{MSH}$ receptor, depressing its activity and competing with the hormone (33). The agouti protein inhibits the melanogenic and the proliferative effects of $\alpha-\mathrm{MSH}$ on normal human melanocytes (31). Therefore, agouti protein may also play a physi- 
ological inhibitory role in human eumelanin production, and might be associated with hypopigmentary disorders such as vitiligo, thus preventing the action of the analogue.

Multiple genetic factors might cause melanocyte dysfunction, or render melanocytes susceptible to environmental, neural or immune stimuli (6). This would explain the diversity of etiologies for vitiligo, and the variable responses of the patients to currently available treatments.

\section{References}

1. Schallreuter KU, Wood J M, Ziegler I, Lemke KR, Pittelkow MR, Lindsey NJ \& Gütlich M (1994). Defective tetrabiopterin and catecholamine biosynthesis in the depigmentation disorder vitiligo. Biochemica et Biophysica Acta, 1226: 181-192.

2. Ortone JP \& Bose SK (1993). Vitiligo: Where do we stand? Pigment Cell Research, 6: 61-72.

3. Souza Fo LGC (1991). Vitiligo. Aspectos imunológicos e correlações com alterações oculares. Doctoral thesis, Faculdade de Medicina, Universidade de São Paulo.

4. Chatain C, Ring J \& Schallreuter KU (1994). Total serum immunoglobulins and atopic symptoms in patients with vitiligo. Dermatology, 189: 27-31.

5. Gilhar A, Aizen E, Ohana N \& Etzioni A (1993). Vitiliginous vs. pigmented skin response to intradermal administration of interferon gamma. Archives of Dermatology, 129: 600-604.

6. Boissy RE, Liu YY, Medrano EE \& Nordlund JJ (1991). Structural aberration of the rough endoplasmic reticulum and melanosome compartmentalization in long-term cultures of melanocytes from vitiligo patients. J ournal of Investigative Dermatology, 97: 395-404.

7. Schallreuter KU, Wood J M, Pittelkow MR, Gütlich M, Lemke KR, Rödl W, Swanson NN, Hitzemann K \& Ziegler I (1994). Regulation of melanin biosynthesis in the human epidermis by tetrahydrobiopterin. Science, 263: 1444-1446.

8. Schallreuter $\mathrm{KU}$, Lemke $\mathrm{R}$, Brandt $\mathrm{O}$, Schwartz R, Westhofen M, Monz R \& Berger J (1994). Vitiligo and other diseases: Coexistence or true association? Dermatology, 188: 269-275.

9. Luger TA, Schauer E, Trautinger F, Krutmann J, Amel J, Schwarz A \& Schwarz T (1993). Production of immunosuppressing melanotropins by human keratinocytes. Annals of the New York Academy of Sciences, 680: 567-570.

10. Morhenn VB, Stage K \& Lee S (1990).
Activated Langerhans cells contain mRNA for pro-opiomelanocortin. J ournal of Investigative Dermatology, 94: 557 (Abstract).

11. Mountjoy KG, Robbins LS, Mortrud MT \& Cone RD (1992). The cloning of a family of genes that encode the melanocortin receptors. Science, 257: 1248-1251.

12. Chhajlani V \& Wikberg J ES (1992). Molecular cloning and expression of the human melanocyte stimulating hormone receptor CDNA. FEBS Letters, 309: 417-420.

13. Mountjoy KG (1994). The human melanocyte stimulating hormone receptor has evolved to become "super-sensitive" to melanocortin peptides. Molecular and Cellular Endocrinology, 102: R7-R11.

14. Abdel-Malek Z, Swope VB, Suzuki I, Akcali C, Harriger MD, Boyce ST, Urabe $K$ \& Hearing VJ (1995). Mitogenic and melanogenic stimulation of normal human melanocytes by melanotropic peptides. Proceedings of the National Academy of Sciences, USA, 92: 1789-1793.

15. Suzuki I, Cone RD, Sungbin IM, Nordlund J \& Abdel-Malek Z (1996). Binding of melanotropic hormones to the melanocortin receptor MC1R on human melanocytes stimulates proliferation and melanogenesis. Endocrinology, 137: 1627-1633.

16. Hadley ME, Sharma SD, Hruby VJ, Levine N \& Dorr RT (1993). Melanotropic peptides for therapeutic and cosmetic tanning of the skin. Annals of the New York Academy of Sciences, 680: 424-439.

17. Hadley ME, Hruby VJ , Chaturverdi DN \& Sawyer TK (1986). $\alpha$-Melanotropin analogues for biomedical applications. In: Moody TW (Editor), Neural and Endocrine Peptides and Receptors. Plenum Press, New York.

18. Dawson BW, Hadley ME, Levine N, Kreutzfeld KL, Dons S, Eytan T \& Hruby VJ (1990). In vitro transdermal delivery of a melanotropic peptide through human skin. J ournal of Investigative Dermatology, 94: 432-435.
19. Dorr RT, Dawson BJ , Al-Obeidi F, Hadley ME, Levine N \& Hruby VJ (1988). Toxicologic studies of a superpotent $\alpha$-melanotropin, [Nle $\left.{ }^{4}, \mathrm{D}-\mathrm{Ph}{ }^{7}\right]-\alpha-\mathrm{MSH}$. Investigation of New Drugs, 6: 251-258.

20. Gehlsen KR, Hadley ME, Levine N, Ray CG \& Hendrix MJ C (1992). Effects of a melanotropic peptide on melanoma cell growth, metastasis, and invasion. Pigment Cell Research, 5: 219-223.

21. Levine N, Sheftel SN, Eytan T, Dorr RT, Hadley ME, Weinrach J C, Ertl GA, Toth K, McGee DL \& Hruby VJ (1991). Induction of skin tanning by subcutaneous administration of a potent synthetic melanotropin. J AMA, 266: 2730-2736.

22. Schwartzmann-Solon AM, Souza Fo LGC $\&$ Arroyo CE (1994). Tratamento do vitiligo através de minienxertos. Medicina Cutanea Ibero Latino Americana, 22: 127131.

23. Falabella R (1993). Repigmentation of segmental vitiligo by autologous minigrafting. J ournal of the American Academy of Dermatology, 9: 514-521.

24. Ferroni EN \& Castrucci AML (1987). A sensitive in vitro toad skin bioassay for melanotropic peptides. Brazilian J ournal of Medical and Biological Research, 20: 213-220.

25. Goldstein E, Haberman HF, Menon IA \& Pawiowski D (1992). Non-psoralen treatment of vitiligo. Part II. Less commonly used and experimental therapies. International J ournal of Dermatology, 31: 314319.

26. Falabella R (1988). Treatment of localized vitiligo by autologous minigrafting. Archives of Dermatology, 124: 1649-1655.

27. Hatchone N, Kato T \& Tagami H (1990). Therapeutic success of epidermal grafting in generalized vitiligo is limited by the Koebner phenomenon. J ournal of the American Academy of Dermatology, 22: 87-91.

28. Gauthier Y \& Surleve-Bazeille J -E (1992). Autologous grafting with noncultured 
melanocytes: A simplified method for treatment of depigmented lesions. J ournal of the American Academy of Dermatology, 26: 191-194.

29. Koga M (1988). Epidermal grafting using the tops of suction blisters in the treatment of vitiligo. Archives of Dermatology, 124: 1656-1658.

30. Löntz W, Olsson MJ, Moellmann G \& Lerner AB (1994). Pigment cell transplantation for treatment of vitiligo: $A$ progress report. J ournal of the American Academy of Dermatology, 30: 591-597.

31. Abdel-Malek Z, Swope V, Suzuki I, Im S, Medrano EE, Nordlund J, Ollmann M \& Barsh $G$ (1995). Paracrine regulation of human melanocytes by $\alpha-\mathrm{MSH}$, endothelin-1, basic FGF, and the agouti protein. Pigment Cell Research, 4 (Suppl): 24 (Abstract).

32. Kobayashi T, Vieira WD, Potterf $B$, Sakai C, Imokawa G \& Hearing VJ (1995). Modu- lation of melanogenic protein expression during the switch from eu- to pheomelanogenesis. Pigment Cell Research, 4 (Suppl): 22 (Abstract).

33. Siegrist $W$, Drozdz R, Cotti R, Willard DH, Wilkinson WO \& Eberle NA (1997). Interactions of $\alpha$-melanotropin and agouti on B16 melanoma cells: evidence for inverse agonism of agouti. J ournal of Receptor and Signal Transduction Research, 17: 7598. 